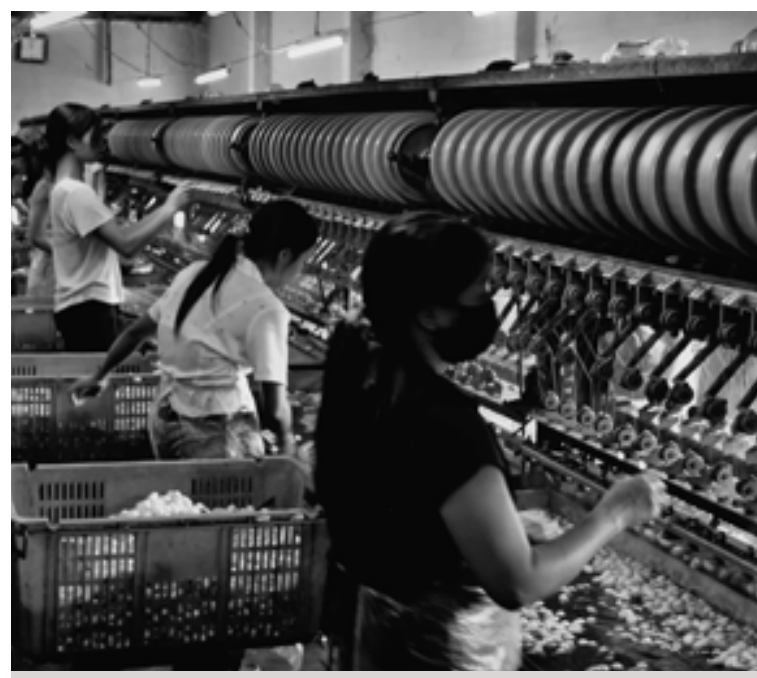

Silk Factory, Central Highlands of Vietnam Photo: Justin Button

\section{Trade Union Reform in One-Party States: China and Vietnam Compared}

\section{Anita Chan}

This essay compares the prospects for union reform in Vietnam and China. In Vietnam, heated debates about how to reform the trade union and the industrial relations system have been ongoing for more than a year, ever since the government signed the now defunct Transnational Pacific Partnership Agreement. That the debate continues among the top leadership and within government bureaucracies indicates that there is no lack of willingness to reform. In China, on the contrary, the Chinese party-state and the official unions are taking the route of suppression of labour activism, indicating grim prospects for union reform.
As I understand it, the new President of the Vietnam General Confederation of Labour is enthusiastic about continuing efforts to 'renovate' grassroots unions even if the Trans-Pacific Partnership Agreement does not go forward... In addition, I understand that the Ministry of Labour

has moved forward with creating a new division of industrial relations that will administer the registration of independent unions.

An ILO Consultant 2 March 2017

From the [Chinese] trade union's standpoint we do not welcome labour NGOs. We even feel antagonistic towards them. My own feeling is about the same.

The union has always taken them as a serious enemy.

An informal employee of the Chinese trade union 4 January 2017

These two comments embody the current concerns over the problems that the Vietnam General Confederation of Labour (VGCL) and the All-China Federation of Trade Unions (ACFTU) are facing in their respective countries. In Vietnam, heated debates about how to reform the trade union and the industrial relations system have been going on for more than a year, ever since the government signed the now defunct Transnational Pacific Partnership Agreement (TPP) with the United States in February 2016. Vietnam's eagerness to become a member of the TPP was due to the promising prospect of quick economic gains connected to the membership. In light of this, there was consensus in the government and the VGCL on the need to enter into this international pact despite the TPP's Chapter 19, which required Vietnam to ensure freedom of association. If the TTP had been implemented, workers would have been permitted to set up their own unions and affiliate themselves to union federations of their choice. This would have meant a fundamental change in Vietnam's political structure necessitating relevant laws to be revised and new institutions created. In 
order to support this complicated process, the United States government had already earmarked four million dollars to fund the International Labour Organisation (ILO) and the Vietnamese Ministry of Labour, Invalids, and Social Affairs (MOLISA) in the development of a plan for the reform of industrial relations in the country within five years.

Sceptics, die-hard critics of one-party states, and those who would have been losers in the new deal-such as the American trade unions-believe that Vietnam signed the TPP for purely economic reasons, and that genuine freedom of association for Vietnamese workers is unlikely to materialise. When Donald Trump withdrew from the TPP in February 2017, scepticism heightened. Indeed it seems that the factions within the Communist Party of Vietnam (CPV) and the VGCL that have not been so supportive of dismantling the monopolistic trade union system are now backtracking. At the time of writing, freedom of association is still under discussion in Vietnam, albeit not as urgently as before. Still, as the quote from the ILO Consultant indicates, the issue is not yet dead and drawing up a programme for trade union reform is now seen as the more urgent task. Had Vietnam been motivated only by economic interests, then these initiatives would have been dropped entirely. That the debate continues among the top leadership and within government bureaucracies indicates that the willingness to reform is also self-motivated. This essay points to the fact that signing the TPP was not a decision solely made on the spur of the moment with economic gains in mind, but also has deeper historical roots.

To strengthen my argument, I will compare Vietnam with China. As many other scholars (including myself) have already discovered, China is an excellent comparator for Vietnam. Both countries are Asian, socialist, one-party states steeped in market socialism, and they are both often criticised as being authoritarian.
The countries' ossified political structures share many common characteristics borne from their Marxist-Leninist origins, but in as much there are varieties of capitalism, there are also varieties of socialism. Having recognised their similarities, identifying their differences and tracing the root causes of their divergences allows us to understand both systems better.

The second quote at the beginning of this essay is taken from an interview with a young university graduate hired by a city-level trade union in Guangdong province. Only one year earlier, for the first time the local government had launched a massive crackdown that saw the arrest and interrogation of some twenty labour NGO activists. The quote-as well as those arrests-shows that, while the Vietnamese are debating how to liberalise the trade union system, the Chinese partystate and the ACFTU are taking the route of suppression. Thus, the prospects for trade union reform in the two countries are very different. But before analysing these prospects, we need to examine the historical roots of why these two one-party states are not equally authoritarian.

\section{Historical, Political, and Structural Differences}

While both the Vietnamese and Chinese unions have been conceived of as Leninist 'transmission belts' between the higher echelons of the party-state and the masses, with an additional role as dispensers of social welfare, in many respects the ACFTU is much weaker than the VGCL. The ACFTU has been in a subservient status under party-state domination since 1949, bereft of any élan of resistance. For eleven years, from 1967 to 1978, it was even disbanded. After Deng Xiaoping came back to power in 1978, he re-established the ACFTU and gave it some magnitude of autonomy, but to this day it remains no more than a very weak bureaucracy. The VGCL, on 
the other hand, has a history of militancy, first against French colonialism and then against American invasion. As Gabriel Kolko has written, 'All wars more or less transcend the control of those leading them...' Because of the war, the union had stronger ties with its constituency. In the South, trade unions battled against American and Vietnamese capitalism. After the war ended in 1975, a legacy of militancy remained, so much so that when I interviewed quite a high-level trade unionist in the mid-1990s, I had the feeling I was talking to a trade union official who still possessed some revolutionary commitment, unlike those Chinese union officials who tended to just spout the Party line. South Vietnam had never been totally absorbed into the fold of the socialist bureaucratic subservient structure when doi moi-that is 'renovation', an expression equivalent to China's 'reform and opening up' (gaige kaifang)-began in the mid-1980s.

Both the ACFTU and VGCL tried to wrest more power from their respective party-states in the late 1980s. While the ACFTU failed to gain anything following the suppression of the Tiananmen Uprising in 1989, the VGCL, in contrast, achieved some independence a year earlier at its 1988 Congress. The then secretary general of the CPV declared that union cadres might voice their ideas independently of the Party and management. Thus, when I first began doing research on Vietnam I was surprised to discover that Lao Dong (Labour), the official newspaper of the VGCL, carried articles in which the union openly staked positions that were different from those of the Party and of MOLISA. One consistent public debate up to this very day has been the VGCL's argument that the minimum wage is set too low for workers' needs. Never has such kind of public discussion appeared in the Chinese Workers' Daily, the ACFTU's mouthpiece, where all Chinese bureaucracies speak with one voice-that of the Chinese Communist Party (CCP). If there were any internal debates on these issues in China, they took place behind closed doors. This difference in the trade union publications alone indicated that in Vietnam there was some room for transparency, and that the VGCL had some space to act independently.

One reason why the VGCL could enjoy this space is partly related to the trade union's organisational structure. The Chinese and Vietnamese administrative systems are similar. In both countries, the Party has control over the appointment of leading union cadres at each level. Leading cadres are also subjected to two management systems, what the Chinese authorities call 'branch dictates' (tiaotiao zhuanzheng) and 'area dictates' (kuaikuai zhuanzheng), with 'branch' referring to ministerial hierarchical chain of commands, and 'area' referring to a command system under the Party at the same hierarchal level. However, while the Chinese bureaucracy is dominated by 'area dictates', Vietnam is more inclined towards 'branch dictates'. In other words, the VGCL's line of command from the top to various lower level unions can override the interests of the Party at the same levels. This permits the VGCL to carry out its assigned mission to represent and protect workers' rights without being trumped by the priorities of the local partystate for economic development. In China, in contrast, local unions are under the control of the local party-state and thus tend to collude with employers, a situation that makes it difficult for them to help workers even if they are so inclined. The difference is further amplified by Vietnam's traditional sectoral trade unions that have a vertical line of command. In China, sectoral industrial unions do exist but they are so weak that they are almost irrelevant.

\section{Different Attitudes and Ways of Handling Strikes}

Since the mid-2000s, both countries have been plagued by wild-cat strikes, especially 
in the labour-intensive export sector. None of these strikes is organised by official grassroots trade unions, and they are thus 'leaderless' strikes. China has chosen to be silent on the legal status of strikes and, without functioning formal channels to resolve their grievances, going on strike has become the only possible strategy for workers to call attention to their plight. Vietnam, in contrast, recognises the right to strike on condition that workers follow a cumbersome application procedure. However, the process is so laborious that out of the several thousands of strikes that broke out in the past two decades not even one can be considered legal. This situation may lead one to conclude that the concession of a legal right to strike is irrelevant in preventing strikes from breaking out.

The difference, therefore, is not in the law but in the authorities' attitude to strikes. Since strikes in Vietnam are officially recognised as a right of the workers-even if they do not comply with the pre-strike procedures-when a strike breaks out, the local Department of Labour and the local trade union immediately arrive on the scene, lambast the management for violating the laws, and negotiate on behalf of the workers. The police too rush to the scene, but they just stand by in case the strikes descend into violence. Once workers' demands are met-usually this happens in a couple of days-production returns to normal.

As for China, since the party-state does not recognise strikes as a right of the workers, the local authorities' attitude towards strikes is generally hostile. They are seen as potentially socially and politically destabilising, and thus anathema to capital investment and economic development. The local union arrives on the strike scene to quell the disturbance rather than to act as a representative of the workers. The police is apt to use force, especially if workers take to the streets. In such a context, Chinese workers see the union, local government, and management as colluding against them. In fact, the attitude of Chinese workers towards the union is not only one of mistrust, but antagonism. Vietnamese workers on the other hand see the primary union as representative of their rights despite its weakness. Here are the surprising results of a survey that Wang Hongzen and I undertook in 2007.

Vietnamese and Chinese Workers' Attitudes towards Factory Trade Unions Do you think the trade union in your workplace represents workers' interests?

\begin{tabular}{|l|l|l|}
\hline & Vietnam & China \\
\hline Yes & $894(85 \%)$ & $100(10 \%)$ \\
\hline No & $58(6 \%)$ & $203(20 \%)$ \\
\hline Don't know & $100(9 \%)$ & $672(67 \%)$ \\
\hline Missing & $2(<1 \%)$ & $33(3 \%)$ \\
\hline Total & $1054(100 \%)$ & $1008(100 \%)$ \\
\hline
\end{tabular}


In other words, though their union is weak, the vast majority of Vietnamese workers still tend to think of the union as an ally rather than an antagonist.

\section{Different Countries, Different Systems}

To summarise, though their workplace union is weak, the two countries are quite different historically, politically, and culturally. On the whole Vietnam is more pluralistic while China is more monolithic. These fundamental preconditions lead to a divergence in the formation of the system of industrial relations. The situation in Vietnam is much more conducive to learning from and working with foreign countries and organisations. For many years, the MOLISA and VGCL have been working closely with international organisations, the most important of them being the ILO, which played an important role in helping and advising Vietnam to revise the strike regulations included in the 2012 Labour Code. They have also been partnering with two trade union support and solidarity organisations: the German Friedrich Ebert Stiftung (FES) and the Australian Union Aid Abroad (APHEDA). The Australian Public Sector Union also helped the VGCL when it was setting up its public sector union in the early 1990s.

Vietnamese trade unionists, unlike their Chinese counterparts, are used to addressing foreign trade unionists and labour activists as brothers and sisters. It reflects their selfidentity as comrades in the international trade union community. The TPP, therefore, should not be seen as the root cause, but as a trigger of Vietnam's decision to reform its industrial relations system, including setting up a system that recognises freedom of association. In fact, it was the VGCL that proposed to the party-state to accept this demand of the American government. The VGCL felt confident enough in its own ability to compete for the loyalty of Vietnamese workers with emerging new trade unions. In mid-2016 during our field research, we saw the relevant Vietnamese bureaucracy stakeholders, in collaboration with the ILO, rolling out programmes of social dialogue and collective bargaining at various administrative levels. There was open discussion that some workers had already agitated to set up new independent unions and the urge was not to suppress them, but to revise the relevant laws to make them reflect this new reality. At the behest of the ILO, Vietnam is consolidating a peak tripartite system. Minimum wage and other labour standards are now set at the national level after intense debate between the three parties-government, employers, and unions. The emphasis of the programme is on strengthening the trade unions' power and their ability to negotiate at different levels. Training on social dialogue techniques is aimed at instructing union officials to identify themselves as representatives of the workers and dissociate themselves from management domination. The ILO's tripartite system is beginning to take shape in Vietnam. However, it seems that the VGCL is on the losing end. After the new minimum wages for various regions were announced in June 2017, the VGCL openly complained that they were too low to meet workers' needs.

In the past two years, the ACFTU has also been in the midst of reforms. Programmes to reform the union in China are not unprecedented, but time and again not much has changed. Direct elections of workplace union committees, campaigns to establish workplace collective bargaining, and the setting up of amalgamated unions at the district or village level for scattered small workplaces have all failed to effect any noticeable changes, except in isolated cases. With strikes breaking out unabated, particularly in Guangdong province, the ACFTU has been blamed for its incompetence in keeping the labour peace.

Meanwhile under Xi Jinping the Chinese 
authorities have intensified their repression of labour activism; labour NGOs have been harassed and some of their staff have been arrested. Foreign contacts are controlled and closely monitored. According to authoritative internal sources, Xi has lambasted the ACFTU, blaming it for having alienated itself from the workers. The unions are criticised for four types of 'ossification'-they are said to have become bureaucratised, hedonistic, behaving like royalty, and acting like functionaries. A new round of reform has been ordered-union officials are to be at one with the people, with more grassroots and amalgamated unions to be set up to provide workers with more services. At the same time, the role of the CCP at the grassroots is also being strengthened, with the Party being cast as the overseer of the union reform.

In January 2017, we had a chance to observe how this programme is being carried out in an industrial zone in Guangdong province. The city union has used its own resources to recruit a dozen or so young university or college graduates to staff one of the zone's community centres. From here they provide social services, run social club activities, and disseminate some labour law knowledge to the workers in the neighbourhood. The office is open until late at night, unlike a regular trade union office that only opens during normal work hours. It is hoped that workers who are active in organising social activities will ultimately become labour activists. If a strike involving more than one hundred workers breaks out in the neighbourhood, it is not the task of the office staff to intervene. They have to wait for the local union and authorities to come to resolve the problem by themselves. The reason why this type of work cannot be taken care of by a regular grassroots trade union office, we were told, is because the union is held back by its own organisational inertia. For all intents and purposes, these grassroots union outposts resemble youth centres and community centres. It is through these services that the city union hopes to be able to satisfy the assigned responsibility of being at one with the masses. But it is not the regular trade union staff who is tasked to do this-it is their surrogates. At best, one can characterise this programme as social work trade unionism.

\section{Anita Chan}

Anita Chan is Visiting Fellow at the Political and Social Change Department, the Australian National University. Prior to that, she was Research Professor at University of Technology Sydney. Her current research focuses on Chinese labour issues. She has published widely on Chinese workers' conditions, the Chinese trade union, and labour rights. She is the co-editor of The China Journal with Jonathan Unger. 